\title{
Exploring Subjective Career Success
}

\author{
Tri Muji Ingarianti ${ }^{1,2^{*}}$, Fendy Suhariadi ${ }^{1}$, Fajrianthi $^{1}$ \\ ${ }^{1}$ Doctoral Program in Psychology, Universitas Airlangga Surabaya \\ ${ }^{2}$ Faculty of Psychology, UMM \\ *Corresponding author: ingarianti2016@gmail.com
}

\begin{abstract}
This exploratory qualitative study attempted to investigate and explore Indonesian employees' subjective career success. Twenty employees from governmental, banking and private sectors were interviewed. The findings showed that there are six themes related to subjective career success. Subjective career success was viewed as making changes, informal learning, satisfaction, life balance, goal fulfillment, and spiritual balance. Interestingly, the majority of participants $(65 \%)$ defined career success as a spiritual balance. They believed that being grateful, showing acceptance, and having opportunities to implement religious tenets in the workplace should be seen as career satisfaction.
\end{abstract}

Keywords: Career success, subjective career success.

\section{INTRODUCTION}

Changes in the nature of career (which becomes increasingly boundaryless and everchanging) and the nature of organizations where individuals possess opportunities to negotiate with their work experience drive researchers and practitioners to revisit several problems and concepts related to career success.

Career success is often depicted as an accumulation of work outcome and psychological accumulation resulting from an individual's work experience [1]. On one hand, career success is reflected by observable success, such as managerial level, promotion, salaries, etc [2][3]. On the other hand, career success can also be described as "subjective" success, an individual's subjective evaluation of various aspects of their career [4].

Subjective career success is pivotal not only for an individual's well-being but also in the organization's sustainability. For instance, employees with positive career belief will exhibit better worklife balance [5] and tend to stay with their seniors when facing career challenges [6][7][8][9]. In contrast, employees with negative career attitudes tend to withdraw from their work or even change their job calling [10]. Therefore, identifying the experience that leads to a positive attitude and career success are crucial both for individuals and organizations. Career success does not only influence individuals but also the organizations they are working in, given that employees' success will, in turn, lead to organizational success [11].

Studies on subjective career success have been significantly developing in the US and Asia, both quantitative and qualitative methods [12] [13]. However, as Spurk and Hirschi [14] suggest, it is necessary to conduct further study on this topic through qualitative framework. Responding to this call, we attempt to extend this field of study by qualitatively investigating subjective career success in non-western contexts.

To date, qualitative studies depicting subjective career success in the Indonesian context is still scarce. Therefore, the present study was conducted to obtain a complete picture of Indonesian employees' subjective career success. Despite the meaning and depiction of career success as individuals in nature, we believe that some similarities could be noticed. More specifically, we attempt to answer a research question on how Indonesian employees conceptualise their subjective career success.

\section{METHOD}

Qualitative approach was applied in order to explore and gain a more in-depth understanding of subjective career success and other issues related to subjective career success. For this purpose, we asked the participants to express their views related to this issue. 
The data were collected using a semi-structured interview. We proposed several questions related to how respondents define their career success. A sample question reads "Considering your career experience, what does career success mean to you?; What makes you feel you have obtained career success?; If you occasionally feel unsuccessful in your career, what makes you feel so?; Describe your work environment, what do you like and what don't you like from it?"

The data were analysed using a thematic data analysis technique. The participants consisted of twenty employees who had already given their consent to participate in the in-depth interview. Half of the participants were male employees, 35 years old on average, with a length of service of more than 7 years. Fourteen employees held a bachelor's degree, three employees held a master's degree, and the rest held an associate's degree. The majority of the participants $(80 \%)$ were married. The participants came from various sectors, including governmental, private (manufacture and banking sectors), and the education sector.

\section{RESULT}

The analysis results generated six themes related to subjective career success. Subjective career success means making changes, informal learning, satisfaction, life balance, goal fulfilment, and spiritual balance.

“... You need to judge your career success based on your own criteria. This is not something you can compare to others' achievement and family's expectation about career" (R 8, Female, Bank Manager)

Subjective career success means making changes. According to some participants, making changes, although only within the scope of their work, could bring a positive impact to other people and the community. They see that success is already obtained when they manage to help other people in their work.

“... being a teacher, I can help my students to be better individuals, make them more prepared to face the future. I enjoy my job as a teacher, I enjoy interacting with students, or listening to their complaints. I even allow them to come to my home if they are permitted...” (R1, Female, Teacher).

“... To train skills to employees, particularly related to how to treat customers, is the most interesting part of my job. Helping them obtain new knowledge and skills they did not get at school is a career success for me...” (R3, Male, Cafe Supervisor)

However, participants who worked as a civil servant did not state this theme. It was due to their type of job that is procedural and administrative in nature, which does not allow them to make changes, even small ones. According to participants who worked as a civil servant, subjective career success means satisfaction. They argued that success is when they could complete the given tasks, helped their colleagues, and achieved a common goal.

"... As a civil servant, it is impossible to change my work procedure. However, career success, to me, is to work in accordance with my skills. I like and can work in an orderliness. I am also satisfied with my job. Being a civil servant makes me feel successful in my career." (R15, female, civil servant)

Subjective career success was also defined as life balance. Participants refer to various ways they could do to maintain long-term commitment. First, some of them highlighted work-life balance, where they felt success when they managed to implement the "work hard-play hard" philosophy. They also emphasize the importance of a healthy lifestyle to exhibit optimal performance and gain the highest level in the organization.

“... When you are unhealthy, I don't think that you will be optimum at work, let alone having an achievement. So, if I am not allowed to do exercise during the break time, I would feel stressed. If the company can provide facilities or policies that support that, I can work optimally. Huge salaries are useless when you are sick." (R13, Male, HR manager).

It was also stated that subjective career success is a process of goal setting and attainment. "Career success for me is to achieve the goal" (R17, male, production supervisor). However, this is not the final goal. It is a cycle of realistic goal setting and attainment. As R11 stated, "to attain the present goal and then set a new goal and go further" (Female, IT supervisor). "In my opinion, career success has no end. There is always a space to go to the next level, to be better in other fields." (R16, Male, Bank)

This study also found that some respondents defined subjective career success as a spiritual balance. The spiritual balance that is meant by the participants is to be successful in life and the afterlife. 
In this regard, individuals can implement their religious values through their present careers.

One of the participants stated that he felt successful in his career when he could perform his religious obligation. "... Praying on time and not hurriedly, or even a work environment with the same atmosphere in performing worship. When it is time to work, we work, when it is time to pray, we pray. So, it will create a balance between work and worship." ((R19, Male, Civil Servant).

Subjective career success also constitutes employees' proactive effort to see their job as their God's plan. "Many people have already had huge salaries and well-established jobs but still find it difficult to fulfill their needs. Alhamdulillah, I do not feel so, although I am just a non-permanent, contract teacher because I believe that Allah always helps His creatures; and Alhamdulillah, I always have enough income to pay for electricity, water, and everyday needs. I have no debt nor any savings. What is important for me is this job is halal." (R2, Male, nonpermanent contract teacher (called Guru Honorer in Indonesia))

Religion and contemplation of the divinity concept are a part of an individual's life in general [15]. Accordingly, religiosity can direct an individual to obtain life meaning [16]. Religion and spirituality provide numerous frameworks for individuals with poor jobs (unwanted by most people) to convince themselves that their job is meaningful [17]. This shows that people perceive their job as sacred and spiritual, not material in nature.

"... As a civil servant, sometimes I have done my best. I perform beyond the target but receive no promotion, and I see it as "okay, it is not my fortune." For me, fortune is God's business, and my fortune surely will come. I have to always do my best at work. Because work is a part of worship (R4, Male, Civil Servant)

" I have a master's degree, but my job is actually for those with associate's or bachelor's degree." I stay here although it does not fit my educational background, because for me this is the only thing I can do. As an administrative staff, I actually have applied for other jobs, but perhaps this is my "fate." I am comfortable with this job. I believe that any job is worship and it is my career satisfaction" (R10 Female, Administrative staff)

"... If considering salary, it is not enough to fulfill the monthly needs, but I think that my children should go to school, my family has many needs to meet. I think that I need to be more grateful for having this job. While so many people are jobless out there. I am grateful because to date, I am still healthy and can meet my family's needs. I have to be always grateful regardless of my job." (R6, Male, Production Staff).

\subsection{Discussion}

When experiencing devaluation of a career or workplace, individuals view that anything that happens is affected by God. This view helped them to accept unfavourable situations and to take the positive side of any event they experience. In line with it, Karakas [18] found that employees who can express their spirituality through their job find their career more satisfying and meaningful, as well as exhibit optimal performance.

Definition of career success involves subjective matters that are incomparable to other people. The present study aimed to show how a job gives meaning to one's feeling of career success. Furthermore, participants felt subjectively successful in their careers when they can give a value-added to other people's life. This is in line with Poon, Briscoe, Abdul-Ghani, and Jones's [19] study that defines career success as, among others, making a difference. Individuals who are subjectively successful in their career may positively affect other people by providing psychological or material assistance to their surroundings.

The study findings mentioned balance, which is conceptualized by Sullivan et al. [20]. More widely, balance covers work and personal life. Some participants possessed personal projects outside their work (e.g., exercising, learning new things).

The present study also found that goal fulfilment and satisfaction resulted in subjective career success. Participants in the present study highlighted the importance of development and explained how problems occurring at work can be transformed into opportunities to develop, which in turn leads to subjective career success. They stated that success is "never" attained in its final form since there is always a chance to develop. This is closely associated with progression and the mechanism to attain it, which is in line with a previous study stating that subjective career success could be seen as a life journey and ongoing development process.

The definition stated by participants was a result of their career-related experiences. Ballout [21] 
defined career success as a set of values, experience, and perception of achievement and satisfaction of an individual related to their career during their life. Further, career success is also related to psychological success that stems from an employee's experience, both in work-related roles or in the family role, and success in establishing a relationship with others. Hall [21] also asserts that psychological success itself stems from personal pride and achievement of life goals, such as inner peace and family happiness. Accordingly, family happiness also serves as one of the pivotal factors that can affect one's perceived career success.

The interesting finding of the present study was that the majority of participants stated that career success means spiritual balance. Neubart and Halbelsleben [22] suggest that spirituality emerges as guidance when an individual is dissatisfied with their job and career. Park and Folkman [23] even argue that strong religious belief makes some individuals believe that everything that happens is part of God's design. It also makes them have positive goals, and even make them stronger when facing any obstacle.

Subjective success basically depends on each individual's definition of his or her achievement, and every individual holds their own reference to define success.

\subsection{Conclusion}

This study concludes that subjective career success is understood as making changes, informal learning, gaining satisfaction, achieving life balance, reaching goal achievement, dan attaining spiritual balance. Spirituality functions as a guidance for individuals to have positive outlook despite any obstacles.

\section{AUTHORS' CONTRIBUTIONS}

TMI conceptualised and wrote the article. FS and F provided guidance related to the writing and advice regarding the concept.

\section{ACKNOWLEDGMENTS}

The authors extend the gratitude to all participants who contributed to the process of implementing this manuscript in this issue. As well as form of support from all respected parties have made this journal qualified to be published.

\section{REFERENCES}

[1] T. A. Judge, D. M. Cable, J. W. Boudreau and R. D. Bretz, "An empiric investigation of the predictor of career success. Pers. Psychol. 48(3) (1995) $485-519$.

[2] N. Dries, R. G. Pepermans and J. Hofmans, "Development and validation of an objective intra-organizational career success measure for managers. J. Organ. Behav. 30(4) (2009) 543-560.

[3] T. W. N. Ng and D. C. Feldman, "Human capital and objective indicators of career success: The mediating effects of cognitive ability and conscientiousness. J Occup. Organ. Psychol. 83(1) (2010) 207-235.

[4] J. H. Greenhaus, S. Parasuraman and W. M. Wormley, "Effects of race on organizational experiences, job performance evaluations, and career outcomes. Acad Manage. 33(1) (1990) 64 - 86.

[5] J. Sturges, N. Conway, K. M. Davey and D. Guest, "A longitudinal study of the relationship between career management and organizational commitment among graduates in the first ten years at work," J. Organ. Behav. 23(6) (2002) 731 - 748.

[6] M. Armstrong-Stassen and N. D. Ursel, "Perceived organizational support, career satisfaction, and the retention of older workers. J. Occup. Organ. Psychol. 82(1) (2009) $201-220$.

[7] R. Donohue, "Examining career persistence and career change intent using the career attitudes and strategies inventory. J. Vocat. Behav. 70(2) (2007) 259-276.

[8] K. A. Eddleston, "The effects of social comparisons on managerial career satisfaction and turnover intentions. Career Dev Int. 14(1) (2009) 87 - 110.

[9] A. Nauta, A. E. M. Van Vianen, B. Van Der Heijden, K. Van Dam and M. Willemsen, "Understanding the factors that promote employability orientation: The moderating impact of employability culture. J. Occup. 
Organ. Psychol. 82(2) (2009) 233 - 251.

[10] M. Simon, B. H. Muller and H. M. Hasselhorn, "Leaving the organization or the profession - A multilevel analysis of nurses' intentions," J. Adv. Nurs. 66(3) (2010) 616 626.

[11] T. A. Judge, C. A. Higgins, C. J. Thoresen and M. R. Barrick, "The Big Five personality traits, generan mental ability and career success across the life span. Pers. Psychol. (1999) 621-652.

[12] M. Arthur, S. Khapova and C. Wilderom, "Career success in a boundaryless career world. J. Organ. Behav. (2005) 177-202.

[13] P. Heslin, Conceptualizing and Ealuating Career Success. J. Organ. Behav. (2005) 113136

[14] D. Spurk, A. Hirschi and N. Dries, "Antecedents and Outcomes of Objective Versus Subjective Career Success: Competing Perspectives and Future Directions. J Manage. 45(1) (2018) 35 - 69.

[15] S. Chan-Serafin, A. P. Brief and J. M. George, "How does religion matter and why? Religion and organizational sciences.," Organ. Sci. 24(5) (2013) 1585 - 1600.

[16] M. F. Steger and P. Frazier, "Meaning in life: One link in the chain from religiousness to well-being. J. Couns. Psychol. 52(4) (2005) 574-582.

[17] J. C. Davidson and D. P. Caddel, "Religion and the meaning of work. J Sci Study Relig. 33(2) (1994) 135.

[18] F. Karakas, "Spirituality and performance in organization: A literature review. J. Bus. Ethics. 94(1) (2009) 89 - 106.

[19] J. M. Poon, J. P. Briscoe, R. Abdul-Ghani and E. A. Jones, "Meaning and determinants of career success: A Malaysian perspective. Eur. J. Work. Organ. Psychol. 31(1) (2015) 21 - 29
[20] S. Sullivan, M. L. Forret and S. M. Carraher, "Using the kaleidoscope career model to examine generational differences in work attitudes. Career Dev Int. 14(3) (2009) 284 302.

[21] H. I. Ballout, "Work-family conflict and career success: The effects of domain-specific determinants. J. Manag. Dev. 27(5) (2008) 437 - 466.

[22] M. J. Neubert and K. Halbesleben, "Called to commitment: An Examination of relationships between spiritual calling, job satisfaction and organizational commitment. J. Bus. Ethics. 132(4) (2014) 859-872.

[23] C. L. Park and S. Folkman, "Meaning in the context of stress and coping. Rev Gen Psychol. 1(2) (1997) 115-144. 